\title{
A new minute eulimid (Caenogastropoda Eulimidae) from the western Iberian Peninsula
}

\author{
Serge Gofas' \& Luigi Romani²* \\ ${ }^{1}$ Departamento de Biología Animal, Universidad de Málaga, Campus de Teatinos s/n, 29071 Málaga, Spain,; e-mail: \\ sgofas@uma.es \\ ${ }^{2}$ Via delle ville 79, 55012 Capannori (Lucca), Italy; e-mail: luigiromani78@gmail.com \\ *Corresponding author
}

\begin{abstract}
An enigmatic small-sized gastropod is recorded on few shells originating from the western Iberian Peninsula. It is assigned to the family Eulimidae relying on shell characters, and compared to species of several genera which share some morphological features with it. It is described as new and provisionally included in Chileutomia Tate et Cossmann, 1898, although with reservation, as we refrain to establish a new genus without anatomical and molecular data which can clarify the phylogenetic relationships of the new species.
\end{abstract}

KEY WORDS Gastropoda; new species; NW Atlantic Ocean.

Received 06.01.2020; accepted 28.02.2021; published online 12.04.2021

\section{INTRODUCTION}

The Eulimidae Philippi, 1853 are a species-rich taxon of marine snails, mostly parasitic of Echinodermata (Warén, 1984). The family comprises about one thousand recent valid species recognized worldwide (MolluscaBase, 2021a), but a more realistic estimate suggests a number of species around 4000 , the most part of them awaiting to be discovered or formally described (Warén \& Gittenberger, 1993; Bouchet et al., 2002). Furthermore, Eulimidae are highly diversified at the genus level (Warén, 1984), possibly due to their strict association with definite echinoderm hosts, and consequently many of them are rare or at least difficult to collect. To date, the taxonomy of this group substantially relies on morphological characters, mainly of the shell, lacking anatomical and ecological information for most species, and lacking even more molecular data. An integrated approach to the Eulimidae sys- tematics and intra-familial relationships is at its very beginning, for instance the phylogenetic position of the Eulimidae within the Caenogastropoda was assessed by molecular means only recently (Takano \& Kano, 2014), leading to consider them as sister-group to the Vanikoridae (Bouchet et al., 2017). Eulimidae are very speciose also in the European seas, counting more than 350 currently accepted species from that area (Costello et al., 2020), plus several other undescribed (A. Warén, pers. com.). In this paper we describe a small eulimid known from a scanty material from the western Iberian peninsula, which we consider sufficiently distinctive to be recognized as a new species.

\section{MATERIAL AND METHODS}

Material examined in the present paper was collected from the following sources. Sediment sam- 
ples from bioclastic bottoms were collected by SCUBA diving, dried, sieved, and sorted for shells. The intertidal sample from Barbate was collected by washing photophilous algae in a bucket of seawater; the residue was then sieved on a $0.5 \mathrm{~mm}$ mesh and sorted for small invertebrates.

Comparisons were made with material figured in recent studies and with appropriate specimens from several localities (see below). This material is currently preserved in private collections and in Muséum National d'Histoire Naturelle, Paris.

Shells were examined through a Lomo MBC-10 stereomicroscope and photographed with a Canon EOS 400D camera, or with a Nikon DXM camera mounted on a Nikon SMZ100 stereomicroscope, and then different views of the same specimen, focused on distinct planes, were assembled using the Combine ZP software (Hadley, 2006). Measurements were taken using an eyepiece micrometer. Protoconch whorls were counted according to Verduin (1977). One shell and details were examined with both XL30 and Quanta 200 Scanning Electron Microscope (SEM) in the Centro de Apoyo Científico y Tecnológico a la Investigación (CACTI) University of Vigo, after air drying and mounting on a SEM stub. Updated taxonomy and nomenclature hereby used follow MolluscaBase (2021) except where otherwise stated.

ABBREVIATIONS AND ACRONYMS. Institutional and private collections. AR: Alessandro Raveggi private collection (Firenze, Italy); LR: Luigi Romani private collection (Lucca, Italy); MNHN: Muséum national d'Histoire Naturelle, Paris (France); SB: Stefano \& Maria Bartolini private collection (Firenze, Italy). Morphometrics. DP: protoconch maximum diameter; DN: nucleus maximum diameter; $\mathrm{H}$ : shell maximum height (in $\mathrm{mm}$ ); LW: last whorl maximum height (in $\mathrm{mm}$ ); NTW: number of teleoconch whorls; NPW: number of protoconch whorls; TW: teleoconch whorl. Other. leg.: collector; SEM: scanning electron microscope; sh(s): shell(s); spm: live collected specimen.

\section{RESULTS}

\section{Systematics}

Classis GASTROPODA Cuvier, 1795
Subclassis CAENOGASTROPODA Cox, 1960 Superfamilia VANIKOROIDEA Gray, 1840 Cox Familia EULIMIDAE Philippi, 1853

Genus Chileutomia Tate \& Cossmann, 1898

Type taxon: Chileutomia subvaricosa Tate et Cossmann, 1898 (Eocene, Victoria, Australia), by original designation.

Chileutomia raveggii $\mathrm{n}$. sp. (Figs. 1-8)

https://zoobank.org:act:4A0DE3B0-5BD9-40438153-5D42E9030556

Eulima sp. - Trigo et al., 2018: 745 and figure [Ría de Camariñas, Galicia, Spain]

TYPe MATERIAL. Holotype: Spain: $1 \mathrm{spm}(1.4$ mm; Figs. 1-3), Barbate, $36^{\circ} 11^{\prime} 05^{\prime} \mathrm{N} 5^{\circ} 56{ }^{\prime} 59^{\prime \prime} \mathrm{W}$, intertidal, Apr. 1994, among Halopteris algae, S. Gofas leg., deposited in MNHN-IM-2000-36521. Paratypes: Spain: 3 shs (Figs. 4-8), Tarifa, Punta Marroquí, SE of the lighthouse, $36^{\circ} 00.0^{\prime} \mathrm{N}$ $05^{\circ} 36.5^{\prime} \mathrm{W}, 37 \mathrm{~m}$, Jul. 2012, in sediment samples from coralligenous substrates, Alessandro Raveggi leg., in AR.

Description OF THE HOlOtyPe (Figs. $1-3$, Table 1). Shell very small $(H=1.24 \mathrm{~mm})$, elongate, subcylindrical, thin but not fragile, transparent and shiny; dead shells becoming whitish and opaque. Protoconch smooth, paucispiral (about 1 whorl), nucleus raised and globular. Transition to teleoconch clear, marked by a distinct, curved scar. Teleoconch up to 2.3 quite regularly convex whorls. Surface smooth except for faint, prosocline and slightly curved growth lines, and 1-2 barely marked incremental scars. Suture oblique, simple, rather shallow. False suture evident, not or little deviated by incremental scars. Last whorl about $7 / 10$ of the total height. Base of the last whorl, slightly curved. Aperture oblique, D-shaped, with parietal and columellar regions forming a continuous, nearly straight line. Outer lip with a well rounded edge, simple but not sharp. Edge of the outer lip (in side view) slightly prosocline, regularly convex, and slightly projecting, smooth inside and slightly flaring on the abapical side. No umbilicus. Operculum thin, translucent, paucispiral, fitting the aperture when the animal is retracted $1 / 4$ whorl inside. Soft parts unknown.

VARIABILITY. The paratypes have no substantial morphological differences with the holotype de- 


\begin{tabular}{|c|c|c|c|c|}
\hline & Holotype & $\begin{array}{c}\text { Paratype } \\
1\end{array}$ & $\begin{array}{c}\text { Paratype } \\
2\end{array}$ & $\begin{array}{c}\text { Paratype } \\
\mathbf{3}\end{array}$ \\
\hline $\mathrm{H}$ & $1.24 \mathrm{~mm}$ & $1.41 \mathrm{~mm}$ & $1.18 \mathrm{~mm}$ & $1.31 \mathrm{~mm}$ \\
\hline NTW & 2.2 & 2.3 & 1.8 & 2.2 \\
\hline NPW & 1 & 1 & 0.9 & 1 \\
\hline DP & $280 \mu \mathrm{m}$ & $285 \mu \mathrm{m}$ & $300 \mu \mathrm{m}$ & $265 \mu \mathrm{m}$ \\
\hline $\mathrm{DN}$ & $170 \mu \mathrm{m}$ & $160 \mu \mathrm{m}$ & $170 \mu \mathrm{m}$ & $160 \mu \mathrm{m}$ \\
\hline $\mathrm{LW} / \mathrm{H}$ & 0.70 & 0.69 & 0.71 & 0.70 \\
\hline Scar(s) & $1.4 \mathrm{TW}$ & $\begin{array}{l}1.2 \mathrm{TW}+ \\
2 \mathrm{TW}\end{array}$ & $1.2 \mathrm{TW}$ & $\begin{array}{l}1.1 \mathrm{TW}+ \\
1.6 \mathrm{TW}\end{array}$ \\
\hline
\end{tabular}

Table 1. Measurements of protoconch and teleoconch of Chileutomia raveggii $\mathrm{n}$. $\mathrm{sp}$.

scribed (Figs. 4-8). For the measurements of protoconch and teleoconch see Table 1.

Eтymology. Named after Alessandro Raveggi (Firenze, Italy), who provided most of the material studied here.

Distribution AND Habitat. Chileutomia raveggii $\mathrm{n}$. sp. is currently known form the west Iberian coast, the disjunct records (Strait of Gibraltar and Galicia, Spain) are probably so scanty due to the minute size and the unremarkable shell which can be easily overlooked or mistaken for juveniles of other species.

The host of Chileutomia raveggii $\mathrm{n}$. sp. is unknown. The habitat which yielded the live-collected holotype hosts many small ophiuroideans and some holothurians, very few starfish, and neither urchins nor crinoids. Eulimids with a holothurian host (e.g. Melanella spp.) are usually very glossy and not translucent. This leaves much probability that the host could be a brittlestar, which were the only echinoderms present in the algal wash, but this is speculative.

Material examined. Chileutomia raveggii $\mathrm{n}$. sp. (see below for details), 4 shs.

Ersilia mediterranea (Monterosato, 1869): Italy, 26 shs, Livorno province, Capraia Island, $43^{\circ} 01^{\prime} 36.0^{\prime \prime} \mathrm{N} 9^{\circ} 50^{\prime} 34.6$ " $\mathrm{E}, 40 \mathrm{~m}$, in SB; $6 \mathrm{shs}$, Catania province, Cannizzaro, $37^{\circ} 32^{\prime} 32.3^{\prime \prime} \mathrm{N}$ $15^{\circ} 09^{\prime} 03.9^{\prime} \mathrm{E}, 35 \mathrm{~m}$, in LR.
Chileutomia miranda (Dautzenberg, 1925): Italy: 1 sh, Catania province, Cannizzaro, 37³2'32.3”'N 1509'03.9'"E, 35 m, in LR; 23 shs (mostly juveniles), Salerno province, Palinuro, $40^{\circ} 01^{\prime} 49.1^{\prime \prime} \mathrm{N} 15^{\circ} 16^{\prime} 03.1$ '”, $30 \mathrm{~m}$, in SB.

Aclis vitrea R.B. Watson, 1897: Spain, 1 spm; Barbate; $36^{\circ} 09^{\prime} 44^{\prime \prime} \mathrm{N} \quad 5^{\circ} 55^{\prime} 34^{\prime \prime} \mathrm{W} ; 29 \mathrm{~m}$; 13/12/1993; E. Manjón leg.; University of Málaga.

Remarks. The taxonomic placement of Chileutomia raveggii $\mathrm{n}$. $\mathrm{sp}$. is tentative, due to the lack of material suitable for anatomic and molecular investigations. The shell morphology, despite being peculiar and diagnostic at the species level, is quite uninformative regarding the generic placement. Some features, although not exclusive, are common of the family Eulimidae, such as the incremental scars, the presence of a conspicuous false suture, and the glossy surface, for which we assign Chileutomia raveggii $\mathrm{n}$. $\mathrm{sp}$. to this family.

Few eulimid genera and species share some shell morphological characters with this new species:

Chileutomia Tate et Cossmann, 1898 (with its synonyms Hoplopteropsis de Morgan, 1916 and Auriculigerina Dautzenberg, 1925), and Menon Hedley, 1900, include few species, both recent a fossils (Warén, 1984; Lozouet, 1999; Garilli \& Messina, 2006; MolluscaBase, 2020b). They are characterized by smooth shells having D-shaped apertures and more or less developed, but clearly detached varices forming an adapical sinus. The latter is also evident on the aperture. The unsculptured protoconch can be paucispiral, multispiral or carinate.

Chileutomia miranda (Dautzenberg, 1925), the sole recent European species of the genus, has a glossy transparent-white shell an a globose and paucispiral protoconch, but differs from Chileutomia raveggii $\mathrm{n}$. $\mathrm{sp}$. for the teleoconch surface covered by microscopic pits (Bouchet \& Warén, 1986; Garilli \& Messina, 2006), the aperture more oval due to the gently curved parietal and columellar regions, the strong varices, anal sinus, more stepped whorls, and finally for attaining a larger size (up to $6.9 \mathrm{~mm}$, Landau \& Marquet, 2001). Juveniles of Chileutomia miranda at $1.2 \mathrm{~mm}$ size would already show the flaring varices which are lacking in Chileutomia raveggii n. sp. (Scaperrotta et al., 2009; pers. obs.). Oceanida de Folin, 1870 is similar to Chileutomia in having a D-shaped aperture, 
but lacks projecting varices and is still larger, with a very acute spire.

Ersilia Monterosato, 1872, another genus of small-sized eulimids (MolluscaBase, 2020c), includes species which are characterized by smooth protoconchs (paucispiral or multispiral) and Dshaped apertures, but possessing ovoidal and robust shells with generally sculptured surface (Garilli, 2004 and herein). Ersilia mediterranea (Monterosato, 1869), the only Recent species living in

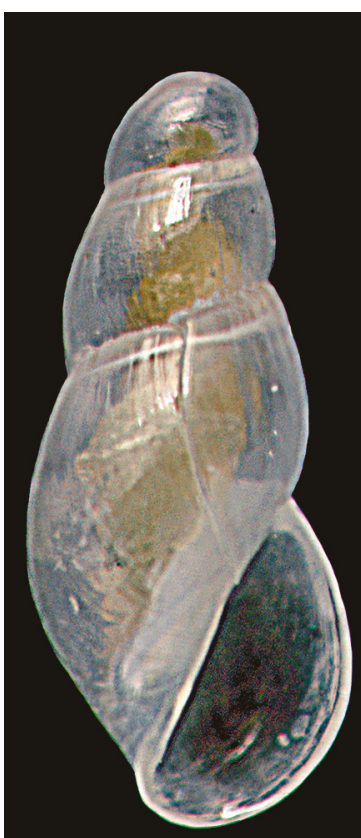

1

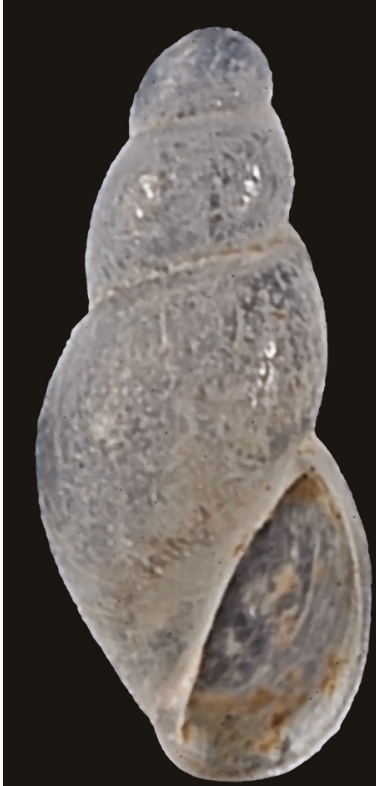

5

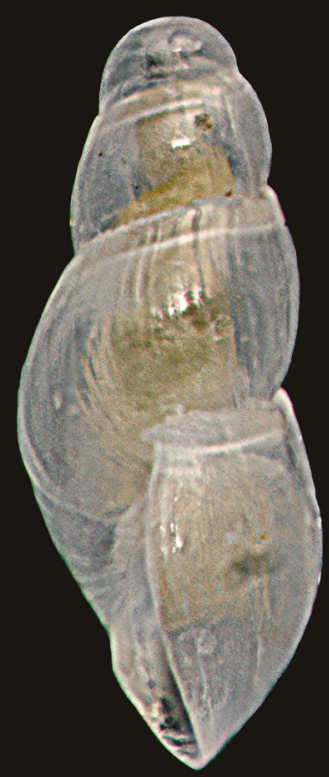

2

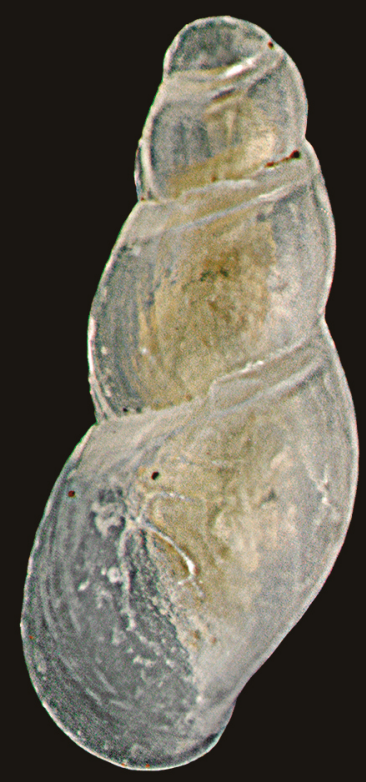

3

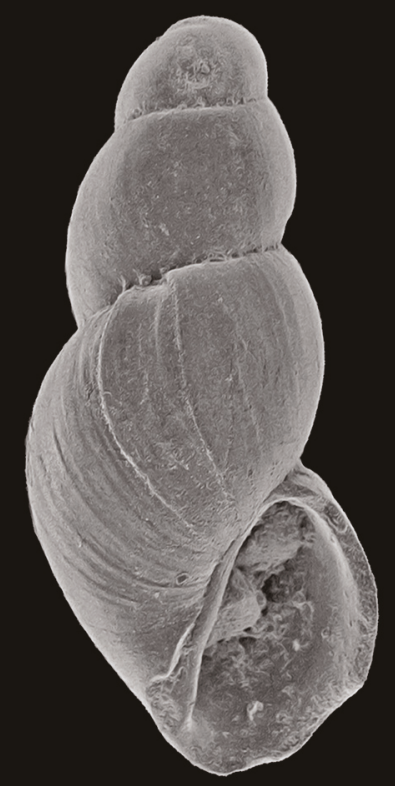

4

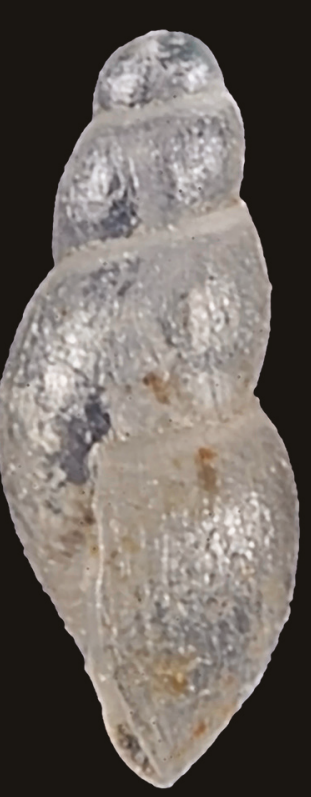

6

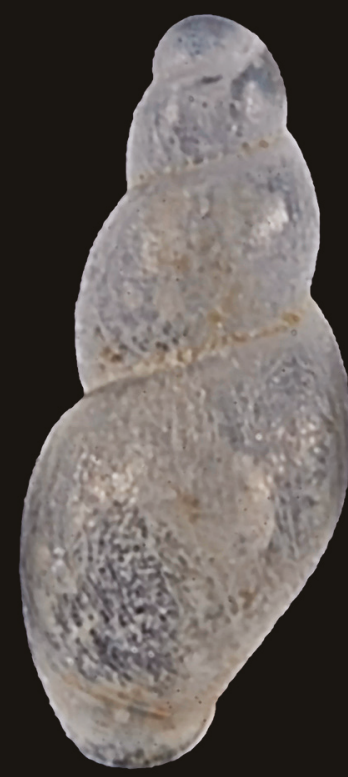

7

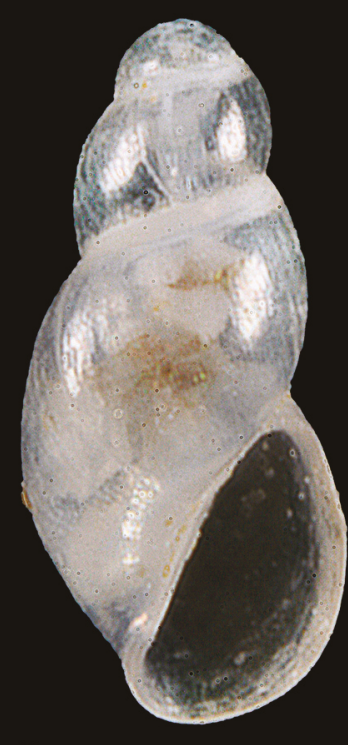

8

Figures 1-8. Chileutomia raveggii n. sp. Figs. 1-3: holotype, Barbate (Spain), H 1.24 mm (MNHN-IM-2000-36521). Fig. 4: paratype 3, Tarifa (Spain), H $1.31 \mathrm{~mm}$, in AR. Figs. 5-7: paratype 1, Tarifa (Spain), H $1.41 \mathrm{~mm}$, in AR. Fig. 8: paratype 2, Tarifa (Spain), H $1.18 \mathrm{~mm}$, in AR. 
the European seas, shares with Chileutomia raveggii $\mathrm{n}$. sp. the paucispiral protoconch and the lined up edges of parietal and columellar regions of the aperture, but differs in shape, sculpture, and colour. The western Atlantic E. stancyki Warén, 1980 has, compared to the congeners, a more slender outline and a smooth teleoconch, but conforms to the genus in all other respects. The fossil species E. aliceae Garilli, 2004 and E. oligocaenica Lozouet, 1999 are also clearly different.

Aclis vitrea R.B. Watson, 1897 (sensu Gofas et al., 2011) is somewhat similar in size and shell texture, but has an oval aperture with a distinct angle between parietal and columellar edges, has an umbilicus, more whorls, and no scars. It remains to be demonstrated that the specimen reported by Gofas et al. (2011) from the same locality as Chileutomia raveggii $\mathrm{n}$. sp. is really conspecific with the Madeiran A. vitrea (Watson, 1897).

We are aware that the generic placement of Chileutomia raveggii $\mathrm{n}$. $\mathrm{sp}$. is rather artificial and that a new genus may be needed, but would refrain from describing a genus without having data on the living animals and on possible phylogenetic relationships of the new species.

\section{ACKNOWLEDGEMENTS}

The following people offered support during fieldwork, research of material in public and private collections, photographs, bibliographic researches, or gave useful advices: Stefano Bartolini (Firenze, Italy), Virginie Héros (Paris, France), Attilio Pagli (Empoli, Italy), Alessandro Raveggi (Firenze); Emilio Rolán (Vigo, Spain), Maria Scaperrotta (Firenze, Italy), Anders Warén (Stockholm, Sweden).

\section{REFERENCES}

Bouchet P., Lozouet P., Maestrati P. \& Heros V., 2002. Assessing the magnitude of species richness in tropical marine environments: exceptionally high numbers of molluscs at a New Caledonia site. Biological Journal of the Linnean Society, 75: 421436.

Bouchet P., Rocroi J.P., Hausdorf B., Kaim A., Kano Y., Nützel A., Parkhaev P., Schrödl M. \& Strong E.E., 2017. Revised classification, nomenclator and typi- fication of gastropod and monoplacophoran families. Malacologia, 61: 1-526.

Bouchet P. \& Warén A., 1986. Revision of the Northeast Atlantic bathyal and abyssal Aclididae Eulimidae, Epitonidae (Mollusca, Gastropoda). Bollettino Malacologico, Supplement 2: 297-576.

Costello M.J., Bouchet P., Boxshall G., Arvanitidis C. \& Appeltans W., 2020. European Register of Marine Species. Eulimidae Philippi, 1853. Accessed at: http://www.marbef.org/data/aphia.php?p=taxdetails\&id $=135$ on $2020-12-30$

Garilli V., 2004. A new species of Ersilia (Caenogastropoda, Eulimidae) from the Plio-Pleistocene of the Central Mediterranean area. Bollettino Malacologico, 39: 91-94.

Garilli V. \& Messina R., 2006. The genus Chileutomia (Gastropoda: Eulimidae) in the Pliocene to Recent Mediterranean area. Bollettino della Societá Paleontologica Italiana, 45: 195-200.

Gofas S., Moreno D. \& Salas C., 2011. Moluscos marinos de Andalucía: I. Introducción general, clase Solenogastres, clase Caudofoveata, clase Polyplacophora y clase Gastropoda (Prosobranchia). II. Clase Gastropoda (Heterobranchia), clase Bivalvia, clase Scaphopoda, clase Cephalopoda, glosario e índices. Servicio de Publicaciones e Intercambio Científico, Universidad de Málaga, Málaga, XVI, 1342 pp; 343-798.

Hadley A., 2006. CombineZP public domain image processing software. https://alan-hadley.software.informer.com/

Landau B. \& Marquet R., 2001. The first fossil record of the genus Chileutomia (Eulimidae: Gastropoda) in the Mediterranean Neogene. Bollettino Malacologico, 37: 223-224.

Lozouet P., 1999. Nouvelles espèces de gastéropodes (Mollusca: Gastropoda) de l'Oligocène et du Miocène inférieur d'Aquitaine (sud-ouest de la France). Partie 2. Cossmanniana, 6: 1-68.

MolluscaBase eds., 2021. MolluscaBase. Accessed at http://www.molluscabase.org on 2021-01-06

MolluscaBase eds., 2021a. MolluscaBase. Eulimidae Philippi, 1853. Accessed through: World Register of Marine Species at: http://www.marinespecies. org/aphia.php? $\mathrm{p}=$ taxdetails\&id $=135$ on 2021-01-06

MolluscaBase eds., 2021b. MolluscaBase. Chileutomia Tate \& Cossmann, 1898. Accessed through: World Register of Marine Species at: http://marinespecies. org/aphia.php? $p=$ taxdetails\&id $=565625$ on 2021-0106

MolluscaBase eds., 2020c. MolluscaBase. Ersilia Monterosato, 1872. Accessed through: World Register of Marine Species at: http://www.marinespecies.org/ aphia.php? $\mathrm{p}=$ taxdetails\&id $=137969$ on 2021-01-06 
Scaperrotta M., Bartolini S. \& Bogi C., 2009. Accrescimenti: stadi di accrescimento dei molluschi marini del Mediterraneo, Vol. I. L'Informatore Piceno, Ancona, $167 \mathrm{pp}$.

Takano T. \& Kano Y., 2014. Molecular phylogenetic investigations of the relationships of the echinodermparasite family Eulimidae within Hypsogastropoda (Mollusca). Molecular Phylogenetics and Evolution, 79: 258-269.

Warén A., 1980. Descriptions of new taxa of Eulimidae (Mollusca, Prosobranchia), with notes on some previously described genera. Zoologica Scripta, 9: 283306.

Warén A., 1984. A generic revision of the family Eulimi- dae (Gastropoda, Prosobranchia). Journal of Molluscan Studies, supplement 13: 1-96.

Warén A. \& Gittenberger E. 1993. Turbo politus Linnaeus, 1758 (currently Melanella polita; Mollusca, Gastropoda): proposed conservation of usage of the specific name, so conserving the specific name of Buccinum acicula Muller, 1774 (currently Cecilioides acicula). Bulletin of Zoological Nomenclature, 50: 107-111.

Trigo J.E., Agras G.J.D., Álvarez Ó.L.G., Sierra Á.G., da Rocha J.M., Dieste J.P., Rolán Mosquera E., Troncoso J.S. \& Urgorri V., 2018. Guía de los moluscos marinos de Galicia. Universidade de Vigo, Vigo, 832 pp. 